\title{
RAD 1 GENOTYPE AND TRIPLE-NEGATIVE BREAST CANCER (TNBC) RISK IN POLISH WOMEN
}

\author{
Beata Smolarz ${ }^{1}$, Marek Zadrożny ${ }^{2}$, Joanna Duda-Szymańska ${ }^{1,3}$, Marianna Makowska ${ }^{4}$, \\ Dariusz Samulak ${ }^{5,6,7}$, Magdalena M. Michalska ${ }^{5}$, Ewa Mojs ${ }^{8}$, Magdalena Bryś 9 , Ewa Forma ${ }^{9}$, \\ HANNA ROMANOWICZ-MAKOWSKA ${ }^{1}$
}

\author{
${ }^{1}$ Laboratory of Molecular Genetics, Department of Pathology, Institute of Polish Mother's Memorial Hospital, \\ Lodz, Poland \\ 2Department of Oncology, Institute of Polish Mother's Memorial Hospital, Lodz, Poland \\ 3Department of Pathology, Medical University of Lodz, Poland \\ 4Regional Hospital in Lodz, Poland \\ 5Department of Obstetrics and Gynaecology, Regional Hospital in Kalisz, Poland \\ ${ }^{6}$ Cathedral of Mother's and Child's Health, Poznan University of Medical Sciences, Poland \\ ${ }^{7}$ Clinic of Gynaecological Surgery, Poznan University of Medical Sciences, Poland \\ ${ }^{8}$ Department of Clinical Psychology, Poznan University of Medical Sciences, Poland \\ 9Department of Cytobiochemistry, University of Lodz, Poland
}

\begin{abstract}
The most lethal damage for the cell among all damage is double-strand breaks (DSB) of DNA. DSB cause development of cancer diseases including the triple-negative molecular subtype of breast cancer. The aim of this work was to evaluate the single nucleotide polymorphism $-135 \mathrm{G}>\mathrm{C}$ (rs 1801320) of the RAD51 gene encoding DNA repair proteins by homologous recombination (HR) in triple-negative breast cancer (TNBC).

We assessed the RAD51-135G >C polymorphism in 50 women with triple-negative breast cancer and in 50 women from the control group. $R A D 51$ polymorphism was analysed by the PCR-RFLP (restriction fragment length polymorphism) technique.

Our results demonstrated a significant positive association between the RAD51 C/C genotype and TNBC, with an adjusted odds ratio (OR) of 5.95 ( $\mathrm{p}=0.002)$. The homozygous $\mathrm{C} / \mathrm{C}$ genotype was found in $68 \%$ of breast cancer cases and $20 \%$ of controls. The variant $135 \mathrm{C}$ allele of $R A D 51$ increased TNBC risk.

This is the first study linking single nucleotide polymorphisms of the RAD51 gene with TNBC incidence in the population of Polish women. In conclusion, RAD 51 polymorphisms may be regarded as predictive factors of triple-negative breast cancer in the female population. Large studies are needed to confirm our findings.
\end{abstract}

Key words: triple-negative breast cancer, $R A D 51$ gene, single nucleotide polymorphism.

\section{Introduction}

Breast cancer is one of the most common malignancy in women. There is almost 10000 newly recognized cases per year in Poland. It means that every year there will be 30 women suffering from breast cancer for every $100000[1]$. Mortality increases $1.6 \%$ every year be- cause cancer is detected too late. Only in $20 \%$ cases the disease is diagnosed in an early stage when chances for recovery are very high. If breast cancer is not cured, only $5 \%$ of women will survive 10 years. For a cured patient the chance of living the next 5 or 10 years without relapse depends on the stage of cancer at the time of beginning therapy. The average rate of 10 -year survival 
for all stages of disease progress is $40 \%$ [1]. The achievements in breast cancer are still not sufficient compared to the scale of the problem. So far there is no initial factor which causes and develops the disease.

Triple-negative breast cancer (TNBC) refers to about $15-20 \%$ of all breast cancer cases. It is characterised by worse clinical outcome and poor prognosis $[2,3]$. TNBC is defined by the lack of expression of oestrogen, progesterone and HER-2 receptors. TNBC is diagnosed more frequently in younger and premenopausal women.

Lately we can observe significant progress in understanding the mechanism of DNA repair. Owing to fast methods of sequencing and DNA sequence analysis from different organisms, the structure and function of DNA repair proteins in mammals are being revealed. In the future, understanding of these processes may prevent diseases based on insufficient DNA repair processes (leading finally to mutations, destabilization of the genome, and cancer development). On the other hand, mutations of repair genes (especially their multiplexing in cancer cells) can make chemotherapy ineffective. Better understanding of DNA repair systems in humans can help in new anticancer drug development, especially enzyme inhibitors responsible for drug resistance of certain cancer types.

There are five known systems of DNA repair: the pathway of direct reversion of damage, base-excision repair (BER), nucleotide-excision repair (NER), mismatch repair (MMR), homologous recombination (HR) and non-homologous DNA end joining (NHEJ). A number of studies suggest a link between deficient repair of DNA double strand breaks (DSB) and genetic

Table I. Pathological features of TNBC patients

\begin{tabular}{lcc}
\hline & \multicolumn{2}{c}{ ToTAL $(\mathbf{N}=50)$} \\
\cline { 2 - 3 } & $\mathbf{N}$ & $\%$ \\
\hline Age (years) & $42(28-63)$ \\
\hline Median (range) & \\
\hline Bloom-Richardson classification & \\
\hline I & 25 & 25 \\
\hline II & 15 & 15 \\
\hline III & 10 & 10 \\
\hline Tumour size grade & & \\
\hline T1 & 10 & 10 \\
\hline T2 & 11 & 11 \\
\hline T3 & 20 & 20 \\
\hline T4 & 9 & 9 \\
\hline Lymph node status & & \\
\hline N0 & 28 & 28 \\
\hline N1 & 11 & 11 \\
\hline N2 & 9 & 9 \\
\hline N3 & 2 & 2 \\
\hline
\end{tabular}

predisposition to hereditary as well as sporadic breast cancer [4-8].

DSB in DNA are repaired by the following two major mechanisms: homologous recombination (HR) and nonhomologous DNA end joining (NHEJ) [9, 10].

RAD51 homolog (RecA homolog, E. coli) (S. cerevisiae) plays an important role in homologous recombination $[11,12]$. It is known that $R A D 51$ gene $-135 \mathrm{G}>\mathrm{C}$ polymorphism may contribute to breast cancer risk [13-17].

Unfortunately, it is difficult to find in the literature reports directly linking this polymorphism in the DNA repair gene $R A D 51$ with TNBC occurrence.

In the present study the association between the $135 \mathrm{G}>\mathrm{C}$ polymorphism of the RAD 51 gene and triplenegative breast cancer was investigated.

\section{Material and methods}

\section{Patients}

Paraffin-embedded tumour tissues were obtained from 50 women with TNBC treated during 2007-2011 at the Department of Oncology, Institute of Polish Mother's Memorial Hospital, Lodz, Poland. The paraffin sections of tumours were taken from archives of the Department of Clinical Pathomorphology in the Institute of Polish Mother's Memorial Hospital. The clinical-pathological characteristics of breast cancer patients enrolled in this study are presented in Table 1. Samples from age-matched, cancer-free women $(n=50)$ served as the control. The Local Ethic Committee approved the study and each patient gave written informed consent.

The breast tissue samples (cancerous and non-cancerous) were fixed routinely in formaldehyde, embedded in paraffin, cut into thin slices and stained with haematoxylin/eosin for pathological examination. DNA for analysis was obtained from an archival pathological paraffin-embedded tumour and healthy samples which were deparaffinized in xylene and rehydrated in ethanol and distilled water. In order to ensure that the chosen histological material is representative for cancerous and non-cancerous tissue, every tissue sample qualified for DNA extraction was initially checked by a pathologist. The DNA samples were extracted using the QIAmp Kit (Qiagen GmbH, Hilden, Germany). DNA purification was achieved according to the manufacturer's instructions.

\section{Evaluation of ER, PR and HER-2}

ER, PR and HER-2 status was determined by an immunohistochemical method as part of the routine clinical practice. Using the immunohistochemical assay, tumours were classified as positive if more than $10 \%$ of the cells showed nuclear staining for the receptor. This information was received together with the 
characteristics of clinical material. The primary antibodies against ER (clone 1D5), PR (clone 1A6) and HER-2 (polyclonal anti-human HER-2) were purchased from DAKO Corporation (CA, USA).

\section{Genotype determination}

Single nucleotide polymorphism $-135 \mathrm{G}>\mathrm{C}$ was determined by polymerase chain reaction-restriction fragment length polymorphism (PCR-RFLP), using primers 5'-TGG GAA CTG CAA CTC ATC TGG-3' (forward) and 5'-GCT CCG ACT TCA CCC CGC CGG-3' (reverse).

$R A D 51135 \mathrm{G}>\mathrm{C}$ genotyping was analysed by PCR amplification of a 175-bp region around nucleotide 135 . This region contained a single $M v a I$ site that was abolished in the $135 \mathrm{C}$ allele. Wild type alleles were digested by $M v a \mathrm{I}$ resulting in $86-$ and $71-\mathrm{bp}$ products. The $135 \mathrm{C}$ allele was not digested by the enzyme, resulting in a single 157-bp product.

The PCR was carried out in a GeneAmp PCR system 9700 (Applied Biosystems) thermal cycler. PCR amplification was performed in a final volume of $25 \mu \mathrm{l}$. The reaction mixture contained 5 ng of genomic DNA, $0.2 \mu \mathrm{mol}$ of each appropriate primer (ARK Scientific GmbH Biosystems, Darmstad, Germany), $2.5 \mathrm{mM}$ $\mathrm{MgCl}_{2}, 1 \mathrm{mM}$ dNTPs and 1 unit of Taq Polymerase (Qiagen $\mathrm{GmbH}$, Hilden, Germany). The PCR cycle conditions were $94^{\circ} \mathrm{C}$ for $60 \mathrm{~s}, 54^{\circ} \mathrm{C}$ for $30 \mathrm{~s}$ then $72^{\circ} \mathrm{C}$ for $40 \mathrm{~s}$, repeated for 35 cycles. After digestion with MvaI for $4 \mathrm{~h}$ at $37^{\circ} \mathrm{C}$ samples were run on $7 \%$ polyacrylamide gel and visualised by ethidium bromide staining. Each subject was classified into one of the three possible genotypes: $\mathrm{G} / \mathrm{G}, \mathrm{G} / \mathrm{C}$ or $\mathrm{C} / \mathrm{C}$.

\section{Statistical analysis}

For each polymorphism, deviation of the genotype frequencies in the controls from those expected under Hardy-Weinberg equilibrium was assessed using the standard $\chi^{2}$ test. Genotype frequencies in cases and controls were compared by $\chi^{2}$ tests. The genotypic-specific risks were estimated as odds ratios (ORs) with associated $95 \%$ intervals (CIs) by unconditional logistic regression. P-values $<0.05$ were considered to be sig- nificant. STATISTICA 6.0 software (StatSoft, Tulsa, OK, USA) was used to perform analyses.

\section{Results}

Table II displays the distribution of genotypes and frequency of alleles of $-135 \mathrm{G}>\mathrm{C}$ polymorphism in patients with TNBC and controls. We found a statistically significant increase in risk of triple-negative breast cancer in a group carrying the $\mathrm{C}$ allele of the $-135 \mathrm{G}>\mathrm{C}$ polymorphism of the $R A D 51$ gene.

All the tumours were graded by a method based on the criteria of Bloom-Richardson. Histological grading was related to $R A D 51$ polymorphism. Histological grades were evaluated in all the cases $(n=50)$; grade I - 25 cases, grade II - 15 cases and grade III - 10 cases. Grades II and III were accounted together for statistical analysis (see Table III). There were no significant differences between distributions of genotypes in subgroups assigned to a particular histological grade $(\mathrm{p}>0.05)$.

Moreover, we did not find any association between TNM and node status parameters of breast cancer and the $135 \mathrm{G}>\mathrm{C}$ polymorphism of the $R A D 51$ gene in single step OR analysis.

\section{Discussion}

Changes in DNA during the organism life time caused by damaging factors and replication defects can lead to serious consequences. It is necessary to have systems repairing DNA, which remove damage and reduce the number of mutations. The systems are characterized by high substrate specificity and specialization. The systems include the direct damage reverse repair pathway, base excision, nucleotide excision, mismatch repair, and recombination repair. Changes in the protein encoding genes can lead to increased numbers of mutations, cancer development and other serious diseases, including inherited diseases. Accumulation related to age leads to transcription disturbances, decrease of overall organism efficiency and development of many diseases including breast cancer [18-21] and finally to death [22].

Table II. Distribution of RAD51 genotype frequencies in patients with triple-negative breast cancer and control group

\begin{tabular}{|c|c|c|c|c|c|c|}
\hline \multirow[t]{2}{*}{$-135 G>C$} & \multicolumn{2}{|c|}{ TNBC $(\mathrm{N}=50)$} & \multicolumn{2}{|c|}{ CONTROL $(\mathrm{N}=50)$} & \multirow[t]{2}{*}{ OR $(95 \% \mathrm{CI}) *$} & \multirow[t]{2}{*}{$\mathrm{P}^{\dagger}$} \\
\hline & NUMBER & $(\%)$ & NUMBER & $(\%)$ & & \\
\hline $\mathrm{G} / \mathrm{G}$ & 8 & 16 & 14 & 28 & 1.00 Ref & \\
\hline $\mathrm{G} / \mathrm{C}$ & 8 & 16 & 26 & 52 & $0.53(0.16-1.74)$ & 0.462 \\
\hline $\mathrm{C} / \mathrm{C}$ & 34 & 68 & 10 & 20 & $5.95(1.94-18.21)$ & 0.002 \\
\hline G & 24 & 24 & 54 & 54 & 1.00 Ref & \\
\hline $\mathrm{C}$ & 76 & 76 & 46 & 46 & $3.71(2.03-6.80)$ & $<0.0001$ \\
\hline
\end{tabular}


Table III. Dependency of genotypes and frequencies of the alleles of $R A D 51$ gene polymorphism on the tumour grade in TNBC patients $(\mathrm{n}=50)$

\begin{tabular}{|c|c|c|c|c|}
\hline $\begin{array}{l}\text { GRADE* } \\
\text { RADS1-135G>C }\end{array}$ & $\begin{array}{c}\mathrm{I}(\mathrm{N}=25) \\
\text { NUMBER }(\%)\end{array}$ & $\begin{array}{c}\mathrm{II}+\text { III }(\mathrm{N}=25) \\
\text { NUMBER }(\%)\end{array}$ & OR $(95 \% \mathrm{CI}) \dagger$ & $P \ddagger$ \\
\hline $\mathrm{G} / \mathrm{G}$ & $7(28 \%)$ & $5(20 \%)$ & 1.00 Ref & \\
\hline $\mathrm{G} / \mathrm{C}$ & $4(16 \%)$ & $4(16 \%)$ & $0.71(0.11-4.31)$ & 0.535 \\
\hline $\mathrm{C} / \mathrm{C}$ & $14(56 \%)$ & $16(64 \%)$ & $0.62(0.16-2.41)$ & 0.729 \\
\hline G & $18(18 \%)$ & $14(14 \%)$ & 1.00 Ref & \\
\hline $\mathrm{C}$ & $32(32 \%)$ & $36(36 \%)$ & $0.69(0.29-1.61)$ & 0.521 \\
\hline
\end{tabular}

*according to Bloom-Richardson criteria; $\dagger$ Crude odds ratio (OR), $95 \%$ CI $=$ confidence interval at $95 \%, * \chi^{2}$

Because of the poor survival of triple-negative breast cancer patients, there is a clinical need to identify new prognostic biomarkers that can be used to predict the therapeutic response and clinical outcomes in TNBC patients to rationalize treatment decisions.

In the present study we investigated whether the single nucleotide polymorphism (SNP) $-135 \mathrm{G}>\mathrm{C}$ in the DNA repair $R A D 51$ gene is associated with the risk of triple-negative breast cancer.

PCR-RFLP was applied for analysis of the chosen $R A D 51$ gene polymorphism. It is based on amplification of the region of polymorphism in a certain gene by PCR and then incubation with a chosen restriction endonuclease specifically recognizing the sequence in one of the polymorphism variants of the gene. The PCR product which contains such a polymorphism is cut into two pieces while products of the wild type are not cut.

Many meta-analyses have demonstrated that $R A D 51$ polymorphism may contribute to breast cancer risk [23-26].

In our earlier studies we investigated the single nucleotide polymorphisms in the RAD 51 gene in sporadic breast cancer $[15,27]$. Our results suggest that the $-135 \mathrm{G}>\mathrm{C}$ polymorphism of the RAD 51 gene may be linked to sporadic breast cancer and can be considered as an additional marker of this disease.

However, the effect of $R A D 51$ polymorphisms focused on molecular subtype triple-negative breast cancer occurrence was not investigated before.

In the present work we analysed the frequencies of the alleles of the RAD51 polymorphisms in samples from 50 patients with triple-negative breast cancer. The present work was performed on an ethnically homogeneous population, which may improve our knowledge regarding to what extent the genotype-phenotype relationship variations are population-related.

The results obtained show an association between the presence of the $135 \mathrm{C}$ variant allele of the SNP and breast cancer for the entire population. The findings indicated that a statistically significantly increased risk of TNBC was associated with $\mathrm{C} / \mathrm{C}$ homozygotes. The relationship between the polymorphism of the RAD 51 gene and clinical-pathological characteristics of triple- negative breast cancer patients was also studied. Breast cancer cases were divided by histological grade and tumour histology. We did not find any association between Bloom-Richardson grading and this polymorphism of the RAD51 gene.

The obtained data suggest that the reported study may be the first observation of the polymorphisms in the RAD51 gene, involved in the DNA repair pathway, to be associated with TNBC risk in the population of Polish women.

Finally, it is postulated that these polymorphisms may be used as predictive factors for breast cancer in the Polish female population. Further studies, conducted on a larger group, are suggested to clarify this point.

\section{The authors declare no conflict of interest.}

\section{References}

1. Didkowska J.U. Epidemiologia nowotworów złośliwych piersi w Polsce. Nowotwory 2007; 57 Suppl. 1: 15-6.

2. Curigliano G, Goldhirsch A. The triple negative subtype: new ideas for the poorest prognosis breast cancer. J Natl Cancer Inst Monogr 2011; 2011: 108-110.

3. Fornier M, Fumoleau P. The paradox of triple negative breast cancer: Novel approaches to treatment. Breast J 2012; 18: 41-51.

4. Keimling M, Deniz M, Varga D, et al. The power of DNA double-strand break (DSB) repair testing to predict breast cancer susceptibility. FASEB J 2012; 26: 2094-2104.

5. Ralhan R, Kaur J, Kreienberg R, et al. Links between DNA double strand break repair and breast cancer: accumulating evidence from both familial and nonfamilial cases. Cancer Lett 2007; 248: 1-17.

6. Jara L, Dubois K, Gaete D, et al. Variants in DNA double-strand break repair genes and risk of familial breast cancer in a South American population. Breast Cancer Res Treat 2010; 122: 813-822.

7. Ricks-Santi LJ, Sucheston LE, Yang Y, et al. Association of Rad51 polymorphism with DNA repair in BRCA1 mutation carriers and sporadic breast cancer risk. BMC Cancer 2011; 11: 278.

8. Romanowicz-Makowska H, Smolarz B, Zadrozny M, et al. Single nucleotide polymorphisms in the homologous recombination repair genes and breast cancer risk in Polish women. Tohoku J Exp Med 2011; 224: 201-208.

9. Jackson SP. Sensing and repairing DNA double-strand breaks. Carcinogenesis 2002; 23: 687-696.

10. Helleday T. Pathways for mitotic homologous recombination in mammalian cells. Mutat Res 2003; 532: 103-115. 
11. Thacker J. The RAD51 gene family, genetic instability and cancer. Cancer Lett 2005; 219: 125-135.

12. San Filippo J, Sung P, Klein H. Mechanism of eukaryotic homologous recombination. Annu Rev Biochem 2008; 77: 229-257.

13. Gao LB, Pan XM, Li LJ et al. RAD51 135G/C polymorphism and breast cancer risk: a meta-analysis from 21 studies. Breast Cancer Res Treat 2011; 125: 827-835.

14. Sun H, Bai J, Chen F et al. RAD51 G135C polymorphism is associated with breast cancer susceptibility: a meta-analysis involving 22,399 subjects. Breast Cancer Res Treat 2011; 125 : 157-161.

15. Romanowicz H, Smolarz B, Baszczyński J, Zadrożny M, Kulig A. Genetics polymorphism in DNA repair genes by base excision repair pathway (XRCC1) and homologous recombination (XRCC2 and RAD51) and the risk of breast carcinoma in the Polish population. Pol J Pathol 2010; 61: 206-212.

16. Krupa R, Synowiec E, Pawlowska E, et al. Polymorphism of the homologous recombination repair genes RAD 51 and XRCC3 in breast cancer. Exp Mol Pathol 2009; 87: 32-35.

17. Synowiec E, Stefanska J, Morawiec Z. Association between DNA damage, DNA repair genes variability and clinical characteristics in breast cancer patients. Mutat Res 2008; 648: 65-72.

18. Mao Z, Jiang Y, Liu X, et al. DNA repair by homologous recombination, but not by nonhomologous end joining, is elevated in breast cancer cells. Neoplasia 2009; 11: 683-691.

19. Silva SN, Tomar M, Paulo C, et al. Breast cancer risk and common single nucleotide polymorphisms in homologous recombination DNA repair pathway genes XRCC2, XRCC3, NBS1 and RAD51. Cancer Epidemiol 2010; 34: 85-92.

20. Krupa R, Sliwinski T, Morawiec Z, et al. Association between polymorphisms of the BRCA2 gene and clinical parameters in breast cancer. Exp Oncol 2009; 31: 250-251.

21. Wang HC, Liu CS, Chiu CF, et al. Significant association of DNA repair gene Ku80 genotypes with breast cancer susceptibility in Taiwan. Anticancer Res. 2009; 29: 5251-5254.

22. Gorbunova V, Seluanov A, Mao Z, Hine C. Changes in DNA repair during aging. Nucleic Acid Res 2007; 35: 7466-7474.

23. Zhou GW, Hu J, Peng XD, et al. RAD51 135G $>$ C polymorphism and breast cancer risk: a meta-analysis. Breast Cancer Res Treat 2011; 125: 529-535.

24. Yu KD, Yang C, Fan L, et al. RAD51 135G >C does not modify breast cancer risk in non-BRCA1/2 mutation carriers: evidence from a meta-analysis of 12 studies. Breast Cancer Res Treat 2011; 126: 365-371.

25. Sun H, Bai J, Chen F, et al. RAD51 G135C polymorphism is associated with breast cancer susceptibility: a meta-analysis involving 22,399 subjects. Breast Cancer Res Treat 2011; 125: 157-161.

26. Wang Z, Dong H, Fu Y, et al. RAD51 135G > C polymorphism contributes to breast cancer susceptibility: a meta-analysis involving 26,444 subjects. Breast Cancer Res Treat 2010; 124: 765-769.

27. Romanowicz-Makowska H, Smolarz B, Zadrozny M, et al. The association between polymorphisms of the RAD51-G135C, XRCC2-Arg188His and XRCC3-Thr241Met genes and clinico-pathologic features in breast cancer in Poland. Eur J Gynaecol Oncol 2012; 33: 145-150.

\section{Address for correspondence}

\section{Beata Smolarz}

Laboratory of Molecular Genetics

Department of Pathology

Institute of Polish Mother's Memorial Hospital

Rzgowska 281/289

93-338 Lodz, Poland

tel. +48422712071

e-mail: smolbea@wp.pl 